\title{
Single Measurement PP Interval
}

National Cancer Institute

\section{Source}

National Cancer Institute. Single Measurement PP Interval. NCI Thesaurus. Code C117772.

An electrocardiographic measurement of the interval between the onsets of two consecutive $\mathrm{P}$ waves. (CDISC) 